NB: This paper is a pre-publication version that appears in lieu of the publisher's own version of record.

\title{
London 2012 (Re)calling: Youth memories and Olympic 'legacy' ether in the hinterland
}

\begin{abstract}
Engendering interest and support among young people was a key strategy for the organisers of the London 2012 Olympic Games (LOCOG). Part of the approach entailed promoting the event as a context and inspirational catalyst to propel young people's proclivities toward, and enduring participations in, sport and physical activity. Although a variety of participatory platforms were entertained, the discipline of Physical education remained a favoured space in which enduring Olympic imperatives could be amalgamated with government policy objectives. In this paper I present data taken from the initial three years of a longitudinal study on young people's engagement with the London 2012 Olympic Games, sport, physical activity and Physical education within the UK's West-Midlands region. I bring together memory scholarship with Olympic critiques, legacy debates, youth work, and discussions about Physical education to conceptualise participant's anticipations and recollections of the London 2012 Olympic Games as a triptych of narrative fragments; each of provides insights regarding youth experiences an, the remnants of Olympic ether in the country's hinterland. The paper offers a means to, subsequently, think differently about how we might play with the qualitative sociological/historiographical moments (experiences, voices, accounts, stories etc.) that we capture in and through our work.
\end{abstract}

\section{Keywords}

Olympics, London, West-Midlands, youth, memory, legacy 
In tandem with the construction of an elite performance sporting spectacle, the London 2012 Organising Committee for the Olympic Games' (LOCOG) plans comprised distinct massparticipatory agendas to mobilise the United Kingdom's citizenry through improved physical activity and sporting praxis (Bullough, 2012; Devine, 2013; Griffiths and Armour, 2013). LOCOG's imperatives to 'inspire a generation' involved delivery strategies that focused on harnessing young people's perceived proclivities for sport and physical activity, engendering nationalistic fervour for sports cultures, reemphasising public health discourses, and, the reimaging of London and the UK as modern, vibrant, and vigorous sporting locales (Mahtani et al. 2013; Thornley, 2012; Weed et al. 2012). The London 2012 Olympic Games would, as far as LOCOG and the government proclaimed, propel an array of economic, infrastructural, environmental and social transformations (in and beyond London); not least of which would precipitate discernible shifts in young people's sporting engagement and physical activity participation (Brown, Cox \& Owens, 2012; Devine, 2013; Mackintosh et al, 2014). More than two years after the London 2012 Olympic Games, however, legacy debate still lingers as scholars, businesses, media outlets, practitioners and members of the public attempt to hold the government and post-games delivery bodies accountable for (or at least mindful of) their Olympic promises (Devine, 2013; Guilianotti et al. 2014). In the domain of Physical education and sport, for example, there has been multifarious discontent. Concerns have, variously, traversed the government's cosy alliances with LOCOG; the haphazard approach to the conceptualisation, resourcing, implementation, and monitoring of legacy policy; curricula shifts and pressures placed upon Physical education as a delivery discipline; the explicit and latent effects on the discipline; and, the insensitivities toward young people's experiences and local contexts (Bloyce \& Lovett, 2012; Bullough, 2012; Girginov, 2012; Griffiths and Armour, 2013; Homma and Masumoto, 2013;). Mindful of England now also hosting the impending Rugby Union World Cup in 2015, this sustained critical examination Olympic legacy of the relationships between mega-sporting investments, youth sport, physical activity and physical education remains timely and profound.

To this end, below, I craft a short series of narratives that cross three years of young people's varied engagements (and/or disengagements) with the London 2012 Olympic Games, sport, physical activity and education. I add to Olympic legacy critiques by illuminating how a specific UK cohort of young people remember London 2012 within their constantly evolving relationship to sport, physical activity and Physical education. Akin to Kennelly and Watt's (2011) research, I demonstrate that youth experiences of the Olympic Games in and beyond host cities are not always positive or inclusive, and moreover, that young people do not always engage with the Olympic Games to the same degree. The point here is not to measure the significance, or extent, of a legacy effect (if indeed such an effect exists); rather, to position young people's experiences as a conversation with and about the Olympic Games, sport, physical activity and Physical education writ large.

While as researchers we might occasionally desire rich, cogent, deep, nuanced and rich participatory accounts from which to articulate fresh academic insights, this particular 
study comprises shorter recollections and reflections. As such, and departing from previous Olympic legacy research, I first draw on Halbwachs ([1950] 1980), Klein (2000), Ricouer (2004; 2009) and Rumford's (2011) theoretical conceptualisations to frame the disparate and messy empirical pieces as a form of memory making (which I present as fragments). The fragments comprise participant excerpts taken from an ongoing longitudinal study of the London 2012 Olympic legacy. The formation of these segments is not to establish a necessarily clear, or neat and tidy, interpretation of what the London 2012 Olympic Games might mean (or might have meant) to this group of young participants. Instead, the aim is to use the event as an experimental reference point around which young people's critical ideas and voices might be orientated. I also locate the fragments within the broader scope of Olympic legacy debates, and, local geo-spatial and temporal context of the West-Midlands.

\section{On the construction of Olympic memory}

A theoretical framework for the construction of youth voices here as a form of collective Olympic narrative can be developed from the work of several scholars; in particular, Anderson (1991), Bell (2003), Halbwachs ([1950] 1980), Klein (2000), Nathan (2003), and Ricoeur $(2004,2009)$. While not specifically attentive to sport (with the exception of Nathan), these scholars examine the historiographical processes of memory making, the ways sociologies of remembering are mobilised, and, the political utility of memory in public discourse. Combined, their investigations helps open a conceptual space to bring together the empirical fragments of young people's Olympic experiences, and, evaluate the fallibility of memory within the context of Olympic legacy (essentially, to question how London 2012 might be remembered, why, by who, and, to what end). Drawing on memory scholarship allows us to move beyond merely conventional representations and interpretations of participatory voices in research into fresh territory in which such voices offer alternative hermeneutic possibilities; specifically here vis-á-vis making new Olympic-related microsociologies and critically orientated social histories of legacy experiences.

The early and revisited work of Halbwachs ([1950] 1980) affords a useful starting point to understand the conceptualisation and politicisation of memory. Writing in the early half of the twentieth century (and largely responding to the consequences of geopolitical reconfigurations on history), Halbwachs underscored the utility of memory and remembering as heuristic devices. That is, as mechanisms through which the past might be understood and considered in relationship to unfolding contemporary contexts. The formation of divergent, yet collective, memories of experience were, for Halbwachs, central to processes of personal, civic, national and global identity formation. Essentially, what mattered was not the partiality and subjectivity of the collective memories, but rather, that they might be operationalised by people in future meaning making. Extending this line of argument, Ricoeur $(2004 ; 2009)$ contends that examinations of the construction and use of shared memories are useful in revealing underlying power relations and political inequalities that govern human society. Ricoeur encourages us to consider fundamental questions of 
'what is the memory?' and 'whose memory is it?'. For Ricoeur, the coalescence of collective memory is essentially a social act entailing selective recollections, recreations, and reimaginings of the past for present purposes. Following this logic it is possible to afford legitimacy and authority to young people's voices within recollections of London 2012, and, in tandem appreciate the breadth, discord, and disjuncture exhibited in their collective expressions. Here in this paper, for example, I draw together a collection of youth voices which I then frame as a unified (though not necessarily unifiable) collective memory arrangement. The underlying intention is to offer a communal orchestration of remembering about the London 2012 Olympic Games and their alleged legacy.

Offering further credence to the utility of memory, Klein (2000) reminds us of the social research shift from conceiving memory as a theoretical anti-historical construct to it becoming a defining feature of progressive sociological and historical research practice. Memories, and in particular the reconstruction and examination of shared memories, provide devices through which scholars might come know, engage with, and represent their communities of interest. As Bell (2003) and Nathan (2003) also add, the construction of memory matters because it offers a means through which individuals and communities are able to re-identify with each other, the spaces they inhabit and the experiences they are a part of. Whether critically-orientated reflection, ambivalent remembering or nostalgic recollection, memory is a powerfully seductive, highly charged and emotive process (Bell, 2003). As Nathan (2003: 60) writes, 'collective memory is a way of expressing sets of ideas, images, and feelings about the past that resonate among people who share a common orientation or allegiance'. Such enterprises of memory making should, Bell (2003) asserts, be cogniscent of historical and political tensions and contradictory forces (in the case of this paper, those presented by the IOC, LOCOG and the government about totalising and positive effects of the Olympic Games and their legacy). As demonstrated shortly, the shared memories of London 2012 young people exhibit in this paper are idiosyncratic, dramatic, affective, and, at times, provocative, and, provide a form of counter-narrative and colourful retort to post-London 2012 discourse.

By framing participant voices conceptually as a collective memory project it is possible to construct a particular narrative of the London 2012 Olympic Games. In this case, a reminiscence that is a melange of anticipation, excitement, joy, optimism and hope, but also, of ambivalence, boredom, discontent, trepidation, anxiety and fear. The Olympic recollections crafted here are, to a degree, celebratory (in that they endorse public revelry for the event and its associated ethos); but, engendered within this effervescence are emotive personal responses that attend to a different set of truths (in which the Olympic Games are provocative, problematic and a divisive intrusion into young people's lives). To recall Cubbit (2007), Raphael (1996) and Ricoeur's (2009) encouragement to appreciate social memories as critical historical articulations, the utility of the evocations here is that this particular cohort of West-Midlands youth are able to be the architects of a new Olympic remembering. This paper is, thusly, a memory exercise in which personal anticipations and 
recollections clash, replicate, contradict, consolidate, challenge and crystallize against the broader socio-cultural context and the political and ideological legacy ether.

Further justification for moulding experiential reflections as a form of memory, and conversely privileging the roles memories play in narrative making, can be found within the domain of youth studies. To better articulate the lived experiences of young people, scholars have underlined the integral role that remembering the past plays in framing and reconstructing youth identities, belonging, social worth, community engagement and geopolitical associations (e.g., Cohen, 1999; Dillabough and Kennelly, 2010; Gille and O Riain, 2002). This work has similarly drawn on theoretical approaches to memory (for example, Cubbit, 2007; Ricoeur, 2009) to underline how young people's fragmentary personal accounts of the past offer useful means to explore power relations and political agency. The recent work of Dillabough and Kennelly (2010), Rumford (2011) and Wright and McLeod (2012), for instance, usefully demonstrates the ways in which reconfigurations of youth experiences, young people's localised practices and understandings of 'the everyday' are framed (and normalised) around memory making processes. These sentiments are also echoed in the work of Cohen (1999), Dillabough and Kennelly (2010), Dillabough and Gardner (forthcoming), and to a lesser extent McLeod (2012), in their various work examining disenfranchised youth within urban settings, and youth lives in the context of neo-liberal global economies.

A synergy of this research is in the attention afforded to young people's consciousness about the past (especially as regards consolidating their civic connections, emotions and identities). Essentially, in the practices of understanding their social worlds, the wider geo-political context, and their respective places therein, memory/historical reflection effectively serves as a spatial and temporal anchoring device shaping young people's personal and collective ways of being (Gille and O Riain, 2002; Dillabough and Kennelly, 2010). Returning to Ricoeur (2009), memory thus constitutes a means of not only routinely accessing an individualised or communal past, but also, is a necessary exercise of identity politics. Although youth recollections may be fleeting, contestable and highly subjective, such scholars highlight the value of investigating what young people remember, and, how threads of the past might be woven into young people's conceptions of self and the spaces they inhabit. Ultimately, what such work underscores is the necessity of appreciating young people's performances of the past as a form of critical historical and sociological discourse (Balibar, 2009). For this paper, the assemblage of young people's anticipations and recollections of London 2012 herein are not merely vestiges of a whimsical sporting nostalgia (though some might rightly fall into this category). Rather, the fragments I reconstruct here represent a nuanced, and on occasion fraught, entanglement with a shared past as part of on-going process of identity making. 


\section{(Physically) activating young people via Olympic legacy}

Augmenting the theoretical conceptualisation, I turn now to examine sport and physical activity imperatives within the United Kingdom and corresponding London 2012 legacy ambitions. Since inception, the Olympic Games have been strongly associated with notions of youth and youthfulness as part of celebrating sport's allegedly universal appeal (Kidd, 2013). In more recent times, however, associations between young people and the Olympic movement, in particular, have been normalised as part of the International Olympic Committee's (IOC) ideological and political strategies to attract and maintain investment in the movement, and, uphold its moral and social credibility and legitimacy (Carmichael, Grix \& Marques, 2012; Girginov, 2012; IOC, 2013; Guilianotti et al., 2014; Kennelly \& Watt, 2011). For the IOC, youth engagement with the Olympic movement forms part of the philosophy that underpins the organisation (IOC, 2013; Kidd, 2013). Subsequently, to win IOC approval, candidate cities (which may or may not become host cities) often attempt to incorporate elements of this ethos within their games proposals (Brown, Cox \& Owens, 2012; Homma \& Masumoto, 2013). London's 2012 Olympic bid, for example, was successful not only because it leveraged the city's multicultural demographic, but also, because it capitalised more broadly on empowering urban youth through promoting increased sport and physical activity participation (Brown, Cox and Owens, 2012; Bullough, 2012; Weed et al. 2012).

Prior to the awarding of the Olympic games to London in 2005, protagonists (led by ex-athlete and politician, Lord Sebastian Coe) formulated a campaign based on using the mega-event to 'inspire a generation' (not only in London, but also, throughout the United Kingdom) (Bloyce \& Lovett, 2012; Carmichael, Grix \& Marques, 2012; Girginov, 2012). The approach positioned the Olympic Games as a mechanism for sporting transformation, and, strategically aligned with broader social reforms and policy debates on sport and activity (Devine, 2013). Key moments over the course of the last decade or so included the development of documents like Game Plan (Department for Culture, Media and Sport (DCMS), 2002), and, investment in meta-data projects such Sport England's Active People Survey (Carmichael, Grix \& Marques, 2012; National Audit Office, 2010; Sport England, 2014; Weed et al. 2012). LOCOG also allied the Olympic Games with overarching issues and concerns; namely, associations between mass participation and public attitudes to health and physical activity, young people's (physical) educational motivations, and, the nation's emotive engagement with sport and physical activity (Bloyce and Smith, 2012; Karadakis and Kaplanidou, 2012).

While seemingly laudable, the approach sat uneasily with physical educators who were discomforted with the politicisation of their discipline to fulfil Olympic purposes and government imperatives (Armour and Dagkas, 2012; Carmichael, Grix and Marques, 2012; Griffiths and Armour, 2013). Although natural synergies may have existed between the Olympic Games and Physical education, the seemingly harmonious association was rightly criticised (Bloyce and Smith, 2012; Griffiths and Armour, 2013; Grix and Carmichael, 2012). 
With regards to the London 2012 Olympic Games, scholars remonstrated that although the event may present some opportunities to inspire and/or improve sport participation, ultimately legacy agendas have compounded physical educators' work. Moreover, the discipline and its constituents have been placed under considerable pressure to increase participation, engagement and performance, and, provide meaningful experiences that resonate into long-term attitudinal and behavioural shifts beyond the classroom (Armour and Dagkas, 2012; Chatzeifstathiou, 2012; Griffiths and Armour, 2013).

Clear disjuncture, thus, emerges between official Olympic legacy imperatives, sensitive and sensible educational curriculum and policy development, disciplinary praxis and practitioners' ontological discomforts. Scholars have gone even further in examining Olympic legacy consequences for young people (within and beyond the context of sport and physical activity engagement) (e.g., Wright, McDonald and Groom, 2003; Johnson et al., 2008; Kennelly and Watt, 2011; and, Mackintosh et al., 2014). Wright et al.'s (2003) work, for instance, stresses that youth perspectives and experiences matter in Olympic legacy dialogues (particularly if such dialogues are attempting to demonstrate disjuncture, disenfranchisement and discord with government agendas, public policy, social inequalities, and global or local market forces). This position is furthered by Johnson et al. (2008) and Mackintosh et al.'s (2014) similar assessments of youth attitudes, behaviours, experiences and understandings of the Olympic Games. As Kennelly and Watt (2011) stress in relation to their comparative work on the Vancouver 2010 Winter Olympic Games and London 2012 Olympic Games, while the IOC and local organizing committees have strategically targeted youth populations (often in deprived areas) as a means of engendering public support and corporate engagement, young people's experiences remain largely absent in policy planning and implementation, and, post-Olympic discussions. Essentially, illuminating young people's perspectives is useful because it not only offers insights into memory and identity, but also, reveals a series of shared (and highly variable) truths young people hold (if only temporarily so) about the legitimacy of the Olympic games and the consequences for their sport, physical activity and physical education experiences. Maintaining criticism of the Olympic Games and its consequences also makes considerable sense given the prevailing, and heightened, sense of moral 'crisis'/'panic' youth appear to be constantly confronted by in contemporary society (Fusco, 2007; McLeod, 2009; Pike, 2007). In this following section I provide brief detail of the localised context as a narrative backdrop.

\section{The setting for memory making}

The cohort for this study come from a secondary school located within a medium-sized metropolitan city (approximately 316,000 inhabitants) in England's west-Midlands region (approximately 113miles from London's Queen Elizabeth Olympic Park) (ONS, 2012). The school is a mixed gender (approximately 50/50\% split), comprehensive (with its intake including students aged 11-18), inner-city establishment comprising some 1507 students (OFSTED, 2013). While the school performs consistently high with regards to national 
examination levels (GCSE or equivalent) (60\% pass rates in 2013 ) in comparison to other schools in the Local authority and against the national average, there has been a marked decline in results from 2012-2013 (Department for Education (DE), 2014). The school has consistently been rated (since 2007/2008) as 'Outstanding' (the highest performance indicator bestowed on educational establishments by the standards authority), and, has developed a strong reputation as a bespoke business and enterprise provider, and, recognised leadership specialist (DE, 2014; OFSTED, 2013). All of the above points strongly to a school well-placed to provide positive, engaging, and hopefully enduringly memorable learning experiences.

In spite of providing (on paper at least) an exceptional environment, the school and others within the city have, subsequent to the arrival of the Conservative coalition government in 2010 and resultant local authority pressures, faced challenges that have changed the educational landscape. Namely, these redirections have reduced resources (e.g. funding streams and teacher/support provision), increased school autonomy (particular in terms of curriculum development, scope and implementation), raised accountability measures, and, altered support arrangements (Bhattacharya, 2012; Greany and Allen, 2014). Such adversities have been also compounded by the city's particular community demographics of above average levels of deprivation, higher than average levels of inhabitants with English as a second language, and, questionable levels of social service provision for young people. Against this picture, young people's educational experiences (including in sport and physical education) have come under increased scrutiny. In response to some of these concerns, the local authority, in conjunction with schools, companies, charities and volunteer organisations, have recently embarked on a longer term strategy to improve the conditions for sport and physical activity at all levels, and, raise its national and regional profile as a 'sporting city' (Coventry City Council, 2014; Evans, 2013; Sport England, 2014).

A key catalyst of this civic rejuvenation process was the opportunity afforded to the city to serve as one of the 6 official partner-city hosts of the London 2012 Olympic Games. Subsequently, in the lead up to, and during the event, the city's Olympic immersion was extensive. For example, the city entertained the Olympic flame overnight during the 70-day torch relay, acted as one of the 22 official (big screen) 'Live' sites set up across the country, hosted events as part of the 2012 Cultural Olympiad, provided ambassadors and volunteers to support the Olympic and Paralympic Games in London, supported local/regional Olympic athletes, served as training camps for visiting Olympic teams, and, fostered Olympic-inspired education and community initiatives. From July $25^{\text {th }}$ to August $9^{\text {th }} 2012$ the city hosted 12 Olympic football matches (including one bronze medal allocation). Some of the city's schools (including the example in this paper) also subscribed to LOCOG's official 'Get Set' school programme. Aligning with the Olympic movement's educational imperatives and government policy agendas, the initiative primarily involved schools subscribing to obtain access to Olympic education resources. Participating establishments also acquired public 
recognition as a 'Get Set' school, and, were rewarded (e.g. with vouchers and prizes from the Games' corporate sponsors, visits from Olympic athletes, resource packs, and selection as a host/training camp for visiting national Olympic delegations) for their efforts to promote London 2012 and the values of the Olympic movement (http://www.getset.co.uk/home; Chatziefstathiou, 2012). Altogether, and not unlike other UK destinations, the extent of Olympic effervescence that came to envelope the city (or, more cynically, the stench of Olympic effluent) was profound and pervasive.

\section{Capturing the memories}

The data herein derives from a longitudinal project that began during the 2011/2012 school year involving a particular Year Seven cohort (initially comprising approximately 170-180 1112 year olds) in one school located in the United Kingdom's West-Midlands region. The approach was informed by ongoing investigations of young people's physical activity and sport participation, and, perspectives of the Olympic Games (for example, Cotton, 2012; Johnson et al 2008; Rikard and Banville, 2006; Tannehill et al, 2013). Drawing on the predominant themes of this research, and also broader sport/educational legacy and Olympic critiques, a 14-item questionnaire was developed to ascertain participant's attitudes and behaviours regarding physical activity, sport and Physical education, experiences, and, feelings (if any) pertaining to the Olympic and Paralympic Games. Questions were also asked in relation to engagements with school or community Olympic events, knowledge of Olympic athletes, visits to the Olympic park in London, ticket acquisition, Olympic-related inspiration levels, and proclivities to increase sport and physical activity participation. A pilot study with similarly aged students was employed to improve the quality of the questionnaire and refine syntax.

The approach was intended to capture a series of discrete/discreet, individualised, concise, evocative moments that may have otherwise remained entrapped within participant's personal Olympic/sporting imaginaries. The objective being to assess whether (and the varying degrees to which) the 2012 Olympic Games may (or may not) continue to resonate with young people outside of London. In what follows I present three fragments (each corresponding to a separate (re)collection year). Representing a proportion of responses from the first three years of the project, each fragment comprises a series of thoughts, attitudes, beliefs and remarks pertaining generally to the areas of sport, physical activity, physical education and the Olympic Games. I then analyse these under the respective titles 'Active anticipations' (circa Pre-London 2012), '(A)musing moments' (circa 2013) and (Ar)rested recollection' (circa 2014). The fragments present readers with a form of post-Olympic narrative. A recourse to London 2012 that is not necessarily seamless, complete, or always comprehensible, but rather (and returning to Ricouer's $(2004 ; 2009)$ remarks about memory making), messy, fluid, contradictory, dynamic, changeable and fleeting. 


\section{Fragment I}

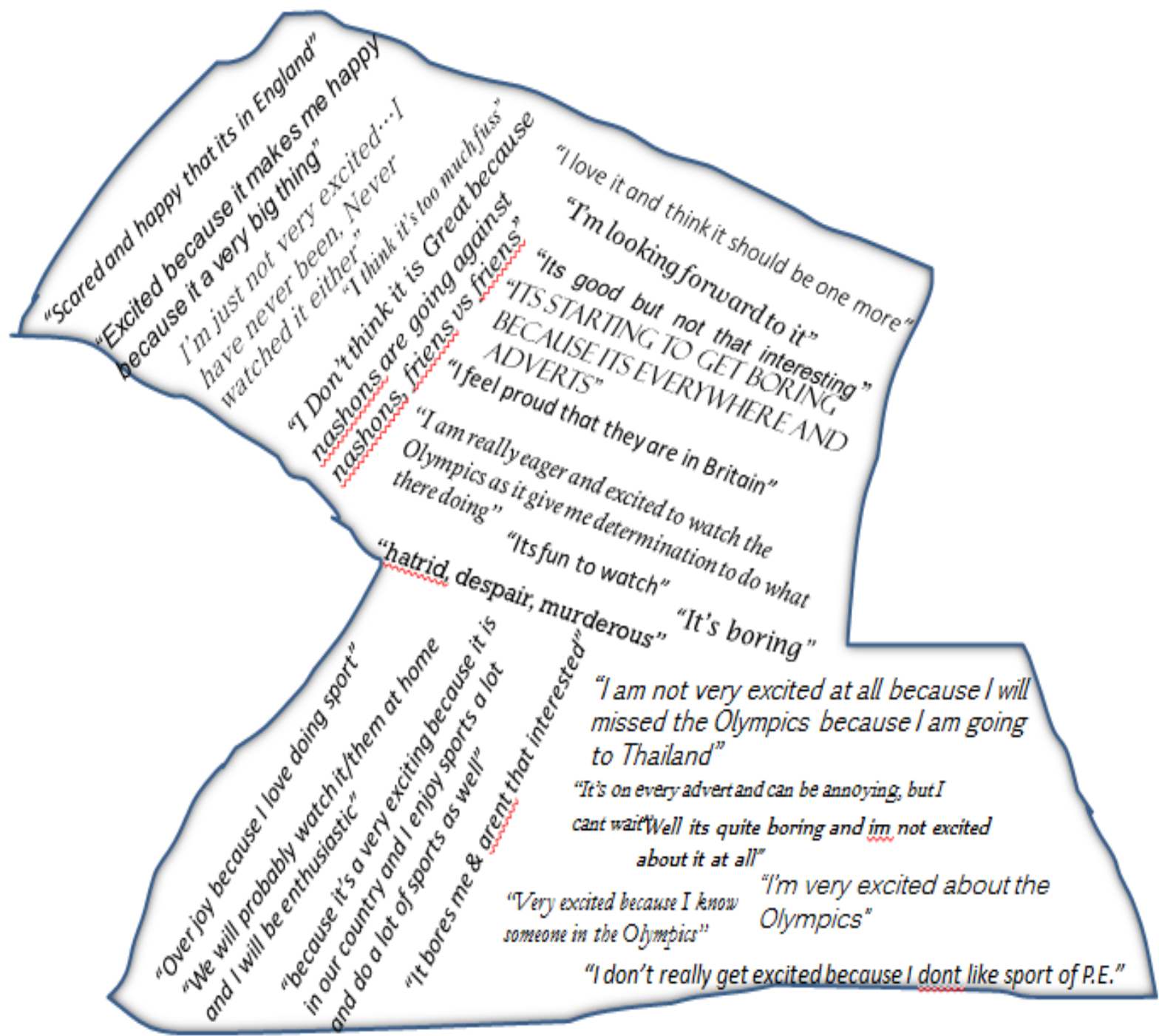

\section{Figure 1. Active anticipations}

This fragment (Figure 1.) captures (in part) the emotive vigour young participants expressed in the lead up to the London 2012 Olympic Games. Here, feelings of fear, elation, enjoyment and anticipation are juxtaposed with a repeated sense of antipathy, ambivalence and annoyance. Participant's fervent passions for sport and the Olympic Games coexist with feelings of frustration and boredom. Beyond, this collective memory collage also meshes deeply personal resonances (for example, about love, determination, and enjoyment) with broader social, political, geographic and cultural reference points (e.g. Britain and nationalistic fervour, (physical) educational experiences, friends and family relationships, and, media and advertising processes). Each component can be read and interpreted separately. However, when collated the effect is the creation of a multi-layered and, invariably, more complex memory; that is, a recollection narrative that is nuanced, nonlinear, discursive and disruptive. To recall Halbwachs ([1950] 1980) and Ricoeur (2004; 2009), the fragment is substantive not merely because it acts as a site upon which individualised experiences of the past might be laid, but rather, as it provides a mechanism 
for the formation of a memory commons. Under such logic, the fragment is a space in which personal, public/civic, national, global and idealistic remembering can represent collective identity enterprise. In this case, the beginning panel of a triptych on young people's London Olympic imaginings.

\section{Fragment II}

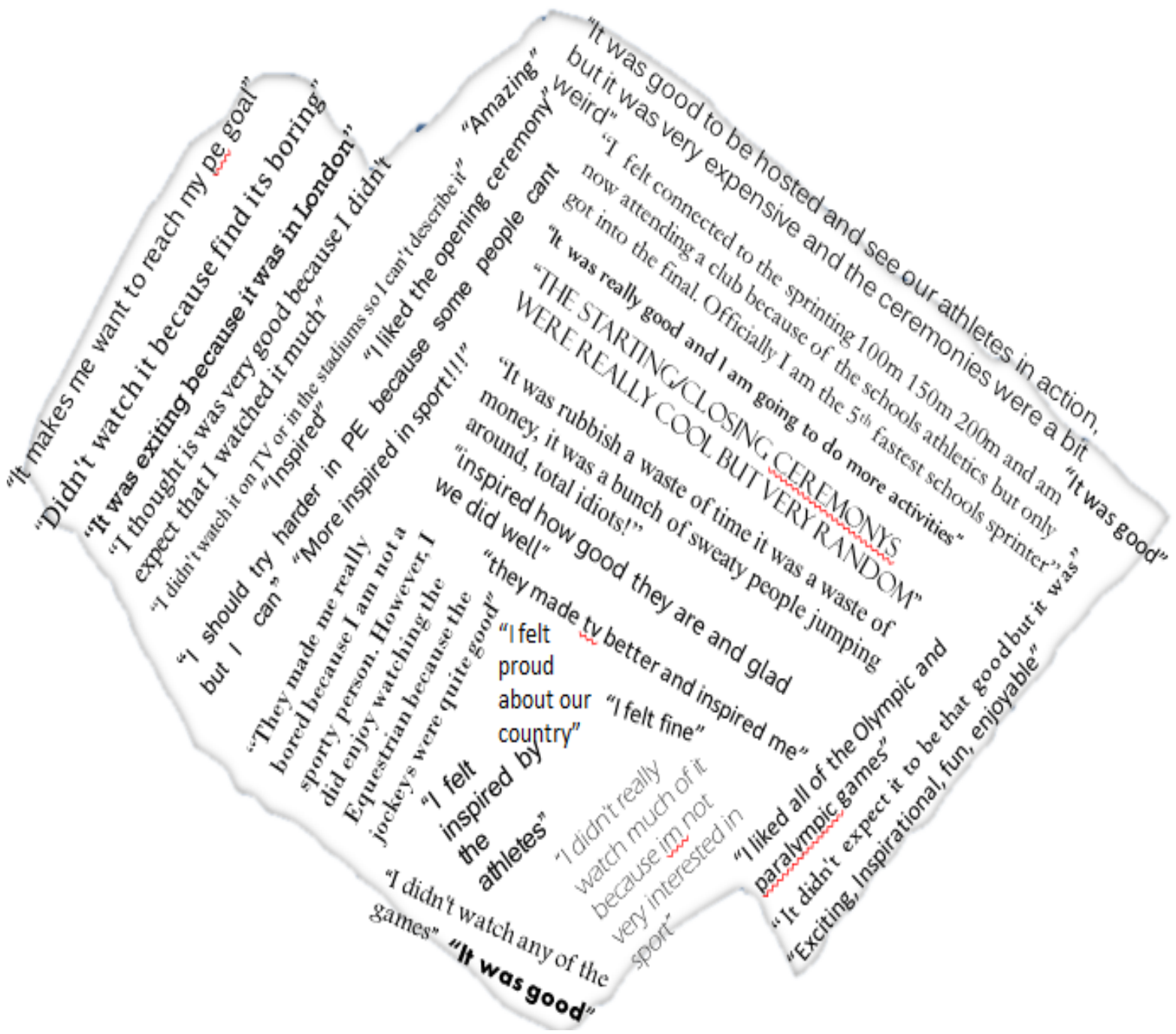

Figure 2. (A)musing moments

This second fragment (Figure 2.) comprises another array of emotive participant responses. Here, however, young people's recollections are quite closely anchored to distinct temporal and spatial referent points (e.g., specific events and/or sports, opening and closing ceremonies, and, athletic achievement). Again, discourses of boredom and ambivalence, as well as amazement, inspiration and enjoyment permeate from the past. In synergy with preevent anticipations, distinct associations between the Olympic Games and participants' identities, lives, and bodies were also pervasive. Alongside these thoughts are also sentimental connections to the nation, and, a general ethos of inspiration. Notwithstanding the prevalence of positive ponderings, cracks of critique are also evident (for example, with regards wasteful expense, 'random' 'weird' ceremonies, and, the idiocy of spectating sweaty 
bodies). Taken in totality (whilst admittedly existing still in partiality), the (re)configuration provides a small insight into some of the diverse interactions and meanings youth draw from their lives and shared experiences. In this case, and to recall Dillabough and Kennelly (2010), Gille and O Riain (2002) and Rumford's (2011) remarks on the significance of memory processes in the interpretation of youth lives, the London 2012 Olympic Games serve here as a focal point around which young people can orientate their identities, corporeal practices (vis. Physical education and activity), and, notions of the 'everyday'. The fragment, thus, crystalizes young people's localised historicization (effectively, their remaking of a time and space that here is represented as emotive, provocative and potentially disruptive). In addition, the unifiable (though not necessarily unified) memory etched onto this fragment also reasserts Kennelly and Watt's (2011) destabilising of the axiom that the Olympics, writ large, will be a positive (and enduring) experience for all young people. The collective voice of participants here certainly speaks to a, darker, counter-narrative in which anxiety, indifference, frustration, vehemence, and Olympic fatigue may play more pronounced roles.

\section{Fragment III}

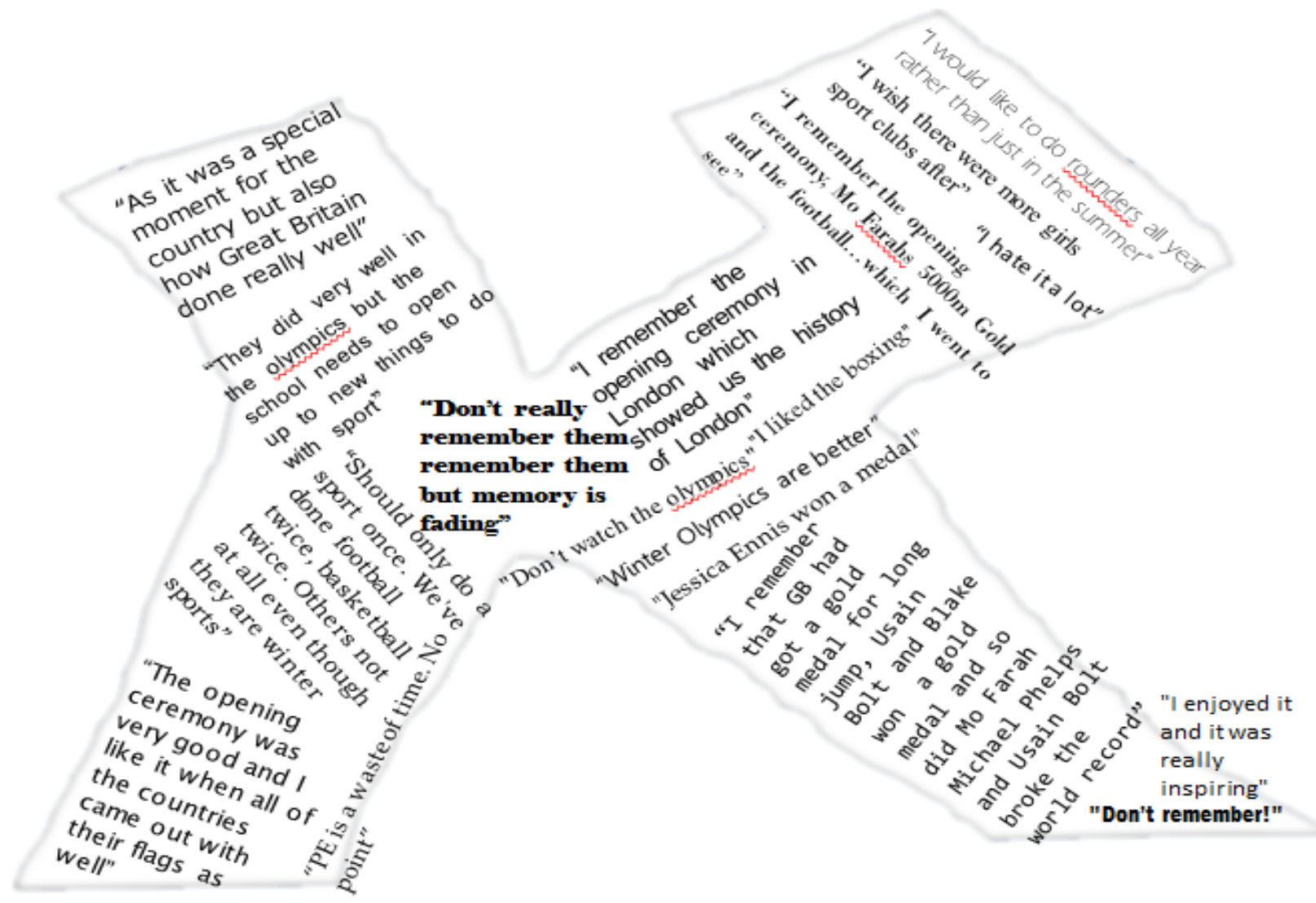

Figure 3. (Ar)rested recollection

Not unlike the predecessors, the last fragment (Figure 3.) exhibits similarly eclectic perspectives. There is continuation of the positive celebrations of the country and its athletes (for example, Mo Farah and Jessica Ennis), joy over nationalistic symbolism, clear 
ceremonial impressions, and, appreciation for the triumphs of global sport superstars (e.g. Michael Phelps and Usain Bolt). As before, some participants rehearsed memories of what they had seen (either in person or via television) and the sports that captured their interest. Others demonstrated their disinterest and disgust. Strong, curt, and expressive sentiments still maintained a presence. While feelings of inspiration loomed for some in the postOlympic context, for others the spectacle seems to have begun slipping from cognition. Returning to my earlier comments about the national and local context for Physical education and Olympic legacy, the reminiscences are, too, also political (namely, in foregrounding young people's concerns about their (physical) educational experiences, curricula foci, and, the provision of school and community resources). In this segment, participants appear to be more explicit with regards to the process of remembering (and forgetting). As such, it is clearer to see the distance being created between the realities of the London 2012 Olympic Games as the past and its contemporary rending as a historical creation within a set of personal and social imaginings. To return readers here to Bell (2003) and Klein's (2000) perspectives, collective memory formations operate as mechanisms of social consolidation; in this case, the coalescences of shared experiences around points of commonality (e.g. the Olympic Games legacy and Physical education legacy).

\section{Mobilising the memories}

The tri-fold fragments presented above creatively orchestrate a brief, yet nuanced, narrative of the London 2012 Olympic Games. I utilised empirical data accordant with aforementioned studies of youth Olympic engagement (e.g. Kennelly and Watt, 2010; Mackintosh et al. 2014; Rikard and Banville, 2006; Tannehill et al., 2013) to craft narrative 'fragments' (unbounded by thematic constraint). The forms I created were a playful, pictorial, exercise to demonstrate the messiness of memory making. The intention was to construct youth recollections as fragmented entities. In essence, to show their collective experiences of the London 2012 Olympic Games not as always linear or lucid, rather, as disrupted (and corruptible), mobile and moveable, freeform, multidirectional, diminishing, re-emergent, sensitive, and dynamic. As Bell (2003), Ricouer (2004) and others argue, all of these qualities (particularly the acceptance of partiality, subjectivity and whimsicality) have a place and role in memory making, and, give credence to its politicization and social and historical utilities. Such arguments encourage the type of Olympic memories entertained herein. Notwithstanding their evident futilities, together the fragments do, I contend, comprise a useful memory triad that reveals something about young people's lives; specifically, in this case, thoughts about sport, physical education and the Olympic Games.

Playful enterprise aside, once the memory has been arrested though, how might it be mobilised? Beyond these fragments, and echoing Halbwachs ([1950] 1980) and Ricoeur (2004; 2009), it is timely to consider here how collective memory might be accounted for in the present, and, contribute to historically informing future trajectories. In what ways, for example, might the fragments serve discussions on Olympic legacy, educational debates, 
and, increasing political, social and moral concerns about young people and their plights? To recall, accounting for young people's presence(s) and improving their lives and experiences via sport was an integral component in LOCOG's delivery rhetoric (Bullough, 2012; Chatziefstathiou, 2012). Alliances with government education and health-based policies in the sector also added gravitas to LOCOG's messages, and, popular discourse regarding the transformative, all-encompassing, potentialities of the mega-event spectacle (Devine, 2013). While attention was directed on the way temporal and spatial context of East London and its young inhabitants, the Games ether invariably filtered outward toward many citizens in the country's hinterlands.

For young people in the West-Midlands (at least the specific cohort in this study), the Olympic Games served as a particular referent point in shaping, variously, their personal belief systems, localised social experiences, historical and symbolic understandings about belonging, dis/appreciations for sport and physical education, and, collective identity formations. The London 2012 Olympic Games mattered, thus, not necessarily as a means of engendering community spirit and increasing young people's physical activity and sporting participation (though this may have occurred), but rather, because the event provided a moment in which to examine youth lives and their engagement with the world. While the London 2012 Olympic Games may have finished, the event (as a memory, concept, idea, and reflection point) still resonates (to varying degrees) in the recesses of participant's minds. As such, their perspectives (and consumptions) of the Olympic Games should still matter. The Olympic spectacle is not essentially 'long-over', but, can be retrieved, reconstituted, and represented (through various processes such as experimented with in this paper) as part of an ongoing, and I would argue important, legacy dialogue.

The argument here is that a recourse to (and validation of) memory can be useful in understanding young people's lives and experiences, revealing their desires and concerns, and, providing a platform upon which a more wide-ranging case to address equality and equity, justice, enfranchisement, and, social transformation might be made. In this case, memories of the London 2012 Olympic Games crystalize a series of deeper concerns about the context, discourses, and idiosyncrasies countering this particular young cohort's sporting and educational worlds. To this end, such an approach is already buoyed by scholars who have argued for the protagonist role memory serves in advancing youth causes (Cohen, 1999; Kennelly and Watt, 2011; Mcleod, 2009; 2012). Collective memories hold value, scholars argue, because they provide deeply personalised (yet shared) insights shaped and anchored in the temporal and spatial realities of everyday life. Moreover, collective recollections can also demonstrate, in sharp relief, the disparate polarities and hierarchies of urban environments and the politically layered fabric of communities therein. The fragments in this paper are, thus, useful for exhibiting how London 2012 was embodied among West-Midlands youth, but also, for disrupting illusions of unification and togetherness that were central to the ethos of Games' organisers and political stakeholders. 


\section{Conclusion}

At a time when multifarious global (and local) circumstances appear to have rendered youth evermore vulnerable, at-risk, in danger, in need, lost, and/or, fraught with moral 'crisis(es)' (Dillabough and Kennelly, 2010; Fusco, 2007; Wright and Mcleod, 2012), attentiveness toward the utility of memory may offer some pause for thought. Against the prevailing neoliberal context in which young people etch out their lives, processes of memory are integral to identity construction and the formation of social narratives that bind (in reality or perception) individuals, groups, communities and societies to each other and their particular contexts (Anderson, 1991; Bell, 2003; Halbwachs [1950] 1980). In this case, that setting was a particular city within the UK's West-Midlands region and a cohort of young people whose lives (and correspondent associations to place and space) were partially orientated by a mega-event sporting spectacle. Irrespective of whatever opportunities the London 2012 Olympic Games afforded, it is evident from the fragments that reflections since have remained fairly colourful, and, continue to inform experiences of sport and Physical education (for better or for worse). The fragments also are helpful in destabilising notions that sport/Physical education might hold a treasured, privileged or necessarily important place in young people's hearts and minds.

Two and a half years on from London 2012, doubt lingers over the consequences of the spectacle; least of all with regards to effects on young people and their the (physical) educational experiences. Taken in consideration with the altered landscapes of education in the UK and resultant pressures on the Physical education discipline mentioned earlier, the experiences represented here may hold some political value (certainly in terms of informing sport policy and Physical education curricula, and, youth welfare debates). Simply put, and notwithstanding the emergent corpus of work, ongoing legacy work still needs to better account for youth presences (in amongst other (dis)affected and (dis)enchanted groups). A return to memory may hold promise in that regard, and, might better inform our work with young people and the debates to which we are a part.

\section{References}

Anderson, B (1991) Imagined Communities: Reflections on the origins and spread of nationalism (2nd edition) London: Verso.

Armour K and Dagkas S (2012) 'Olympism' and education: A critical review. Educational Review 64 (3): 261-264.

Balibar E (2009) We, the people of Europe?: Reflections on transnational citizenship. Princeton: Princeton University Press.

Bell D (2003) Mythscapes: Memory, mythology, and national identity. British Journal of Sociology 54 (1): 63-81. 
Bhattacharya B (2013) Academy schools in England. Childhood Education 89 (2): 94-98.

Bloyce D and Lovett E (2012) Planning for the London 2012 Olympic and Paralympic legacy: A Figurational analysis. Sport Policy and Politics 4 (3): 361-377.

Brown R, Cox G and Owens M (2012) Bid, delivery, legacy - creating the governance architecture of the London 2012 Olympic and Paralympic Games legacy. Australian Planner 49 (3): 226-238.

Bullough S J (2012) A new look at the latent demand for sport and its potential to deliver a positive legacy for London 2012. International Journal of Sport Policy and Politics 4 (1): 39-54.

Carmichael F, Grix J and Marques D P (2012) The Olympic legacy and participation in sport: An interim assessment of Sport England's Active People Survey for sport studies research. International Journal of Sport Policy 5 (2): 229-244.

Chatziefstathiou D (2012) Olympic education and beyond: Olympism and value legacies from the Olympic and Paralympic Games. Educational Review 64 (3): 385-400.

Cohen P (1999) Rethinking the youth question: Education, labour and cultural studies. Durham, NC: Duke University Press.

Cotton R (2012) Inspiring a generation? Young people's views on the Olympic Games' legacy? British Journal of School Nursing 7 (6): 296-301.

Committee, International Olympic (2013) Olympic Charter. Lausanne: International Olympic Committee.

Coventry City Council (2014) Our journey: How Coventry celebrated London 2012. Available at: http://london2012.cswp.org.uk/london-2012-team-gb-hopefuls (accessed 15 June 2014).

Cubbit G (2007) History and Memory. Manchester: Manchester UP.

Department for Culture, Media \& Sport (2002) Game Plan. London: DCMS.

Department for Education (2014) School performance tables. Available at: http://www.education.gov.uk/cgi-bin/schools/performance/ (Accessed 15 June 2014).

Devine C (2013) London 2012 Olympic legacy: A big sporting society? International Journal of Sport Policy and Politics 5 (2): 257-259.

Dillabough J-A and Gardner P (forthcoming) 'Of Time and the City': Young People's Ethnographic Accounts of Identity and Urban Experience in Canada. In: Smeyers P, Bridges D, Burbules N. and Griffiths M (eds) International Handbook in Interpretation of Education Research, Berlin: Springer.

Dillabough J-A and Kennelly, J (2010) Lost youth in the global city. London: Taylor \& Francis. 
Evans R (2012) Local Authority Report. Available at: http://covsport.org.uk/media/downloads/coventry-sports-and-leisure-report (Accessed 15 June 2014)

Fusco C (2007) 'Healthification' and the promises of urban space: A textual analysis of place, activity, youth (PLAY-ing) in the city. International Review for the Sociology of Sport 42 (1): 43-63

Gille Z and O Riain S (2002) Global ethnography. Annual Review of Sociology 28: 271-295.

Girginov V (2012) Governance of London 2012 Olympic Games legacy. International Review of the Sociology of Sport 47 (5): 543-588.

Girginov V and Hills L (2008) A sustainable sports legacy: creating a link between the London Olympics and sports participation. The International Journal of the History of Sport 25 (14) 2091-2116.

Greany T \& Allen T (2014) School improvement networks and system leadership in Coventry: Evaluating progress, areas for development and possible next steps. London: London Centre for Leadership in Learning.

Griffiths M \& Armour K (2013) Physical education and youth sport in England: Conceptual and practical foundations for an Olympic legacy? International Journal of Sport Policy \& Politics 5 (2): 213-227.

Grix J and Carmichael F (2012) The Olympic legacy and participation in sport: An interim assessment of Sport England's Active People Survey for sport studies research. International Journal of Sport Policy and Politics. Epub ahead of print DOI: 10.1080/19406940.2012.656675 1-16.

Grix J and Carmichael F (2012) Why do governments invest in elite sport? A polemic. International Journal of Sport Policy and Politics 4 (1): 73-90.

Giulianotti R, Armstrong G, Hales G and Hobbs D (2014) Sport Mega-Events and Public Opposition: A Sociological Study of the London 2012 Olympics. Journal of Sport and Social Issues. Epub ahead of print 14 April DOI: 10.1177/0193723514530565

Halbwachs M ([1950] 1980) The collective memory. New York: Harper and Row.

Homma K and Masumoto N (2013) A theoretical approach for the Olympic legacy study focusing on sustainable sport legacy. The International Journal of the History of Sport 30 (12): 1455-1471.

Karadakis K and Kaplanidou K (2012) Legacy perceptions among host and non-host Olympic Games residents: A longitudinal study of the 2010 Vancouver Olympic Games. European Sport Management Quarterly 12 (3): 243-264.

Kennelly J and Watt P (2011) Sanitizing Public Space in Olympic Host Cities: The Spatial experiences of marginalized youth in 2010 Vancouver and 2012 London. Sociology 45 (5): 765-781. 
Kidd B (2013) The global sporting legacy of the Olympic movement. Sport in Society 16 (4): 491-502.

Klein K L (2000) On the emergence of memory in historical discourse. Representations 69: 127-150.

Mackintosh C, Darko N, Rutherford Z and Wilkins, H-M (2014) A qualitative study of the impact of the London 2012 Olympic on families in the East Midlands of England: Lessons for sport development. Sport, Education and Society. Epub ahead of print. DOI: 10.1080/13573322.2014.881337. 10 February 2014. 1-23.

Mahtani K R, Protheroe J, Slight S P, Demarzo M M, Blakeman T, Barton C A, Brijnath B and Roberts N (2013) Can the London 2012 Olympics 'inspire a generation' to do more physical or sporting activities? An overview of systematic review. British Medical Journal Open 3: 1-9.

McLeod J (2009) Youth studies, comparative inquiry and the local/global problematic. Review of Education, Pedagogy and Cultural Studies 31 (4): 1-23.

McLeod J (2012) Vulnerability and the neo-liberal youth citizen: A view from Australia. Comparative Education 48 (1): 11-26.

Nathan D (2003) Saying it's so: A cultural history of the Black Sox scandal. Urbana: University of Illinois Press.

Office for Standards in Education, Children's Services and Skills (2013) OFSTED report. Available at: http://www.ofsted.gov.uk/inspection-reports/find-inspectionreport/provider/ELS/139292 (accessed 19 August 2014).

Office for National Statistics (2012) 2011 Census: Key statistics for local authorities England and Wales. Available at: http://www.ons.gov.uk/ons/rel/census/2011census/key-statistics-for-local-authorities-in-england-and-wales/stb-2011-censuskey-statistics-for-england-and-wales.html (accessed 21 August 2014).

Pike E (2007) Revisiting the 'Physical Activity, Sexual Health, Teenage Identity Construction Nexus. International Review for the Sociology of Sport 42 (3) 309-319.

Raphael S (1996) Theatres of Memory. London: Verso.

Ricoeur P (2004) Memory, History, Forgetting. Chicago: University of Chicago Press.

Ricouer P (2009) Living up to death. Chicago: University of Chicago Press.

Rikard G L and Banville D (2006) High school student attitudes about physical education. Sport, Education and Society 11 (4): 385-400.

Rumford C (2011) Citizens and borderwork in contemporary Europe. London: Routledge.

Sport England (2014). Active People Survey. Available at: https://www.sportengland.org/research/about-our-research/active-people-survey/ (accessed 7 February 2014). 
Tannehill D, MacPhail A, Walsh J and Woods C (2013) What young people say about physical activity: The Children's Sport Participation and Physical Activity. Sport, Education and Society. Epub ahead of print. DOI: 10.1080.13573322.2013.784863. 1-21.

Thornley A (2012) The 2012 London Olympics: What legacy? Journal of Policy Research in Tourism, Leisure and Events 4 (2): 206-210.

Weed M, Coren E, Fiore J, Wellard I, Mansfield L, Chatziefstathiou, D and Dowse, S (2012) Developing a physical activity legacy for the London 2012 Olympic and Paralympic Games: A policy-led systematic review. Perspectives in Public Health 132 (2): 75-79.

Wright J, MacDonald D, \& Groom L (2003) Physical activity and young people: Beyond participation. Sport, Education and Society 8 (1): 13-33.

Wright K and McLeod J (2012) Public Memories and Private Meanings: Representing the "Happy Childhood" Narrative in Oral Histories of Adolescence and Schooling in Australia, 1930s-1950s, Oral History Forum d'histoire orale 32, Published in 'Making Educational Oral Histories in the 21st Century', 1-19. 